\title{
鉄道駅におけるモニターカメラから得られる歩行者挙動データの活用に関する研究 *
}

\author{
A Study on Usage of Pedestrian Behavioral Data from Video Camera in Railway Stations *
}

日比野直彦 ${ }^{* *}$, 山下良久 $* * *$, 内山 久雄 $* * * *$ By Naohiko HIBINO **, Yoshihisa YAMASHITA *** and Hisao UCHIYAMA ****

\section{1.はじめに}

高齢社会の到来，価値観の多様化等に伴い，鉄道サ 一ビスにおいてもその改善が強く要求されるようにな ってきた．また，大都市圈，特に首都圏においては都 市化の進展による空間的制約や運賃収入の低迷による 財政的制約により，これまでのような新線建設等の大 規模整備を行なうことは困難な状況であり ${ }^{1)}$ ，新たな 視点での整備が必要不可欠となっている.このような 中，鉄道事業者は，利用者の潜在的な二ーズを見出し， 新たな価值観を創造するという視点から鉄道駅整備に 重点をおいた施策を展開している ${ }^{2 !}$ ．例えば，鉄道駅 構内のユニバーサルデザイン化や「エキナカ」の再整 備等が行なわれ，交通結節点としてのみならず地域の 拠点としての「駅」に向けた鉄道駅リフォームが現在 進行している3゙.

一一方, 1995 年の地下鉄サリン事件, 2001 年の米国 における同時多発テロ事件, 2004 年のスペインにおけ る列車爆破テロ事件等，一般市民を巻き込んだ事件が 頻発している.「水と安全は夕夕」と言われていた我 が国も，そのような社会通念は消えつつあり，

“safety”だけでなく "security”に対する関心も高まり つつある.このような背景を受け, 特に公共の場にお いて保安を目的とした監視カメラの設置が進んでいる. 東京駅, 品川駅, 新宿駅等の主要なターミナルにおい ては, 券売機や改札口付近は勿論のこと, 通路に沿つ て高密度に監視カメラが設置されている. プライバシ 一の侵害にあたるとして異議を唱える声も一部にはあ るが，犯罪の抑止や事故・災害時に早急な対応が可能 となる等, 人々の生命や財産を守るという点で社会的 貢献度は大きく, 今後さらなる整備が進められると予 想される.

*Keywords : 鉄道計画, 歩行者交通行動

** 正 員, 博 (工), (財) 運輸政策研究機構 運輸政策研究所 (東京都港区虎/門 3-18-19 号 虎ノ門マリンビル3F TEL 03-5470-8415, FAX 03-5470-8419

*** 正 員, 修(工), 東京理科大学 理工学部 助手 千葉県野田市山崎 2641 , TEL 04-7124-1501 (内線 4018)，FAX 04-7123-9766

****7工只, 工 博, 東京理科大学 理工学部 教授
先述のとおり, 安全かつ快適な空間を目指し, 多く の鉄道駅で整備が進められており，エスカレータ，エ レベータの設置数, 駅構内の商業施設数, 監視カメラ の設置数等を見る限り，一定の成果は得ていると言え るであろう。しかしながら，今なお発生する混雑や交 錯に起因する事故等を鑑みるに，歩行環境における改 善すべき課題は多い，その改善策の 1 つとして歩行者 挙動を整備に反映することが考えられる.

そこで, 本研究では, 歩行環境における歩行者挙動 を 24 時間 365 日観測可能な監視カメラのビデオ映像に 着目する. 現時点においては，保安目的で設置されて いる監視力メラから得られる映像を目的外利用するこ とは困難である．しかしながら，これらの映像より歩 行環境の改善を検討するうえで有効となる基礎デー夕 が取得できること，基礎デー夕を活用した鉄道駅整備 の計画手法が具体的に提案されることにより, 監視力 メラの社会的役割や設置の目的を拡大するきっかけに なるものと筆者らは考える.このような点を踏まえ， 本研究では, 鉄道駅構内にビデオカメラを設置し, そ こから取得する映像から (1) 歩行者挙動デー夕 (4 次 元パスデー夕 $P i(x, y, z, t))$ を取得し, (2) そのデー夕 から歩行者挙動特性を明らかにし, (3) 鉄道駅における 歩行環境整備を念頭においた歩行者シミュレーション モデルを構築することを目的とする.

\section{2. 既往研究の整理と本研究の位置づけ}

本研究は, (1) 歩行者挙動デー夕の取得, (2) 歩行者 挙動特性分析, (3) 歩行者シミュレーションモデルの構 築によって, 分析フローが構成されている. ここでは, これらに関連する既往研究を整理し, 本研究の位置づ けを示す.なお, 本研究では, 直進, 停止, 回避, 追 い越しといった一連の歩行動作とこれらに伴う歩行速 度の変化等を総称し，「歩行者挙動とする.

\section{(1)歩行者挙動データの取得方法に関する研究}

歩行者挙動を扱う分析は, 土木計画学の分野にお いても古くから行なわれてきた. そのデー夕取得方 法は, 分析対象エリアをビデオカメラにて撮影し, その映像から手作業により歩行者の軌跡デー夕を作 
成する方法が主流であった．この方法は，歩行者の 検出ミス, 軌跡の作成ミス等が少なく高精度のデー 夕が取得できるものの, 分析者の作業量が多く, 狭 い空間, 短時間, 少サンプルの分析にならざるを得 ないといつた問題点を有していた.

近年, 急速なIT, 画像処理技術等の発展により, 先 述の問題点は解決されつつある. 例えば, 白井ら ${ }^{4)}$ は, ビデオカメラの設置状態やビデオ画像から得られる 背景の状態等の条件別に歩行者の追跡に適応可能な 処理方法を整理した論文を発表している. 筆者ら5) は, 鉄道駅構内におけるビデオ画像に対してテンプレー トマッチングを行なうことにより，歩行者を検出し， その測地座標データを自動取得するシステムを開発 している. 北澤ら ${ }^{6)}$ は, 鉄道駅構内の歩行者を対象に, レーザーセンサにより連続的にその位置を特定し, 移動軌跡を取得する方法を提案している. 朝倉ら》は, PHSを用いて歩行者の移動軌跡を取得する調査手法を 提案している.

このように, 歩行者挙動デー夕取得方法に関する 研究は幾つかなされており, 現在では比較的容易に 高精度のデータが取得可能となっている.

\section{(2) 歩行者挙動に関する研究}

歩行者挙動に関する研究は, 土木計画学の他にも, 人間工学, 建築学等, 幅広い分野で取り組まれてい る. この中でも, 特に建築学分野においては多くの 研究がなされており, 様々な状況下における歩行者 挙動について分析されてきた. 例えば, 加藤ら 横断歩道を対象として, 対向流がすれ違う際に, 歩 行者同士が集団化し, 幾つかの層が形成される現象 をエントロピー指標により定量的に示している. ま た, 高柳ら”は, 駅構内および横断歩道を対象として, 歩行者が集団化していく様子や集団の形状が変化し ていく様子を視覚的に表現している.

これらの研究に示されているように, 歩行者をあ る程度まとまった群集流として捉えた歩行者挙動分 析が, 今までの主流となっている.

\section{(3)歩行者シミュレーションモデルに関する研究}

歩行者シミュレーションモデルは，これまでにも 多数構築されている. これらは, 目的によって歩行 空間の表現方法が異なっており, ネットワーク型モ デルとセル型モデルに大別される.

歩行空間をノードとリンクで表現するネットワー ク型モデルは, 目的地までの経路選択行動を扱う場 合に用いられることが多い. 金森(1) は, 鉄道駅の木 一ムから改札口への経路選択を対象として, リンク
毎に移動コストを属性別に設定し, エスカレー夕等 が設置された際に混雑するリンクを予測している.

一方, 細かなセルで歩行空間を分割して表現する セル型モデルとして, 磁気モデル, セルオートマト ン法を用いたモデルが挙げられる. クーロンの法則 を応用した岡崎 ${ }^{11)}$ 15) による磁気モデルでは, 歩行者 と壁，柱等の障害物に正の磁極を，また歩行者の目 的地点に負の磁極を与え, 目的地の吸引力により歩 行者は移動する．歩行者に作用する全ての力を計算 し, 加速度, 移動する位置が決定するモデルである. また，セルオートマトン法を用いたモデルとしては, 森下ら ${ }^{16)}$, 近田 $5^{17}$, 筆者ら ${ }^{18}$ が挙げられる. セルオ 一トマトン法によるモデルでは, 局所的な範囲にお ける歩行者挙動を近傍則により規定し，各歩行者は その近傍則に従って移動するセルを決定する.

ネットワーク型, セル型モデルの特徵より, 歩行 動線の検討にはネットワーク型モデルが, また, 歩 行空間の検討にはセル型モデルが適していると考え られる.

\section{(4)本研究の分析フローおよび位置づけ}

時間带, 曜日, 季節等によって同じ鉄道駅におい ても歩行者の流動が異なることから，快適な歩行環 境に向けた整備を検討するためには，ある一時点の データではなく連続的に観測されたデー夕を取得す ることが望ましい，そのため, 本研究では，常時撮 影可能な既設の監視カメラに着目し, これらの活用 を念頭におきビデオ映像からのデー夕取得を試及る. 取得には，筆者ら5) が開発したシステムを援用する.

取得した4次元パスデータより, 従来の研究のように 歩行者を群集流として捉えることに加え，個々の歩 行者に着目し，歩行速度，交錯現象等について言及 する.これらを通して, 歩行者挙動の特性の一端を 明示する. 歩行者挙動特性分析での知見を歩行者シ ミュレーションに反映するためには, 回避や追い越 しといつた個々の歩行者挙動を再現できるように空 間を表現しなくてはならない. そのため, 本研究で は, セル型モデルを適用した歩行者シミュレーショ ンモデルを構築する.

以上を踏まえ, 監視カメラの活用を念頭におき, 「ビデオ映像を有效活用し，そこから得られる歩行者 挙動を考慮した鉄道駅整備は, 鉄道サービスの向上 に繋がる」という一つのコンセプトを提案するととも に, 既往研究を応用し, 幾つかの分析を組合せるこ とにより, 快適な歩行環境整備の実現に向けた計画 手法を示すものとして本研究を位置づける. 


\section{3. 鉄道駅構内歩行者流動調查}

\section{(1) 調査対象駅}

東武春日部駅において2003年10月に「鉄道駅構内歩 行者流動調査」を実施している ${ }^{19}$. 春日部駅は，放射 状路線の東武伊勢崎線之環状路線の東武野田線の乗 換え駅である. 平成12年大都市交通センサスによる と, 1日あたりの乗降客数は約 67,000 人, 朝の通勤・ 通学時間帯 (7 :30 8:29) の伊勢崎線・野田線間 における乗換え旅客数は約 13,400 人である. 春日部駅 の地理的位置を図一 1 に, 横断図を図一2に, 施設概 況を表-1に, 通勤・通学時間帯の利用者数を表 -2 に示す.

春日部駅を調査対象駅として選定した理由は, (1) 大規模駅においては, バリアフリー施設の整備をは じめ, ある程度の駅整備が進んでおり，今後の整備 は郊外部の乗換え駅がその対象になると考えられる こと, (2) 改札口が2つで, 連絡通路には各ホームに直 接連絡する階段が設置されていることから，旅客の 流動パターンがある程度決定されており, 歩行者同士 の交錯が発生しやすい箇所を想定しやすく, ビデオカ メラの設置において撮影方向等の検討がしやすいこ との大きく2点である.

\section{(2) 調査概要}

2003年10月19日(日)，20日(月) $6: 30 \sim 20: 00$ に ビデオ撮影を実施している. 春日部駅には, 監視力 メラが設置されていないため, 監視カメラを模した 汎用ビデオカメラ 28 台㧍よびドーム型カメラ4台をモ ニターカメラとして使用している. 図一3に春日部駅 の構造およびカメラの設置箇所を示す．このように 多数のモ二ターカメラを設置する理由は, (1) 先述の ように本研究は監視カメラの活用が念頭にあり, 既 に導入されている駅では高密度に監視カメラが設置 されていること, (2) 場所により発生しやすい歩行者 挙動が異なると考えられること, (3) シミュレーショ ンモデルで必要となるOD情報を観測する必要がある ことの3点である.

使用するビデオカメラの画素数は25万画素, ビデ オカメラの設置高さは，通路や階段で多少異なるが 概ね $3.3 \mathrm{~m}$ である. なお, 本調査は, 東武鉄道株式会 社の許可を得て研究目的で実施しており, 調査に当 たっては調査目的, 調査主体を利用者に明らかにし ている. そのため, 個人情報保護法 ${ }^{20)}$ の適用除外の対 象となり法律に抵触するものではない，また，事業 者, 利用者に提示した目的でビデオ映像を利用して おり，目的外利用には当たらない。

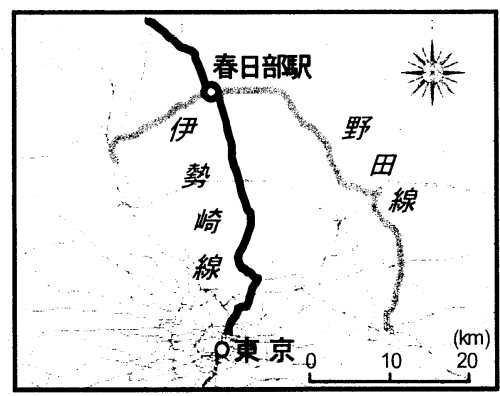

図-1 春日部駅の位置

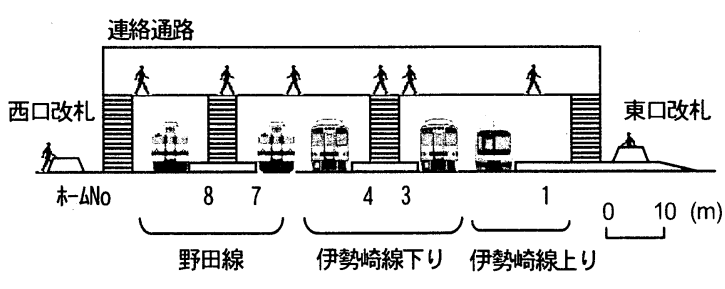

図一2 春日部駅の横断図

表-1 春日部駅の施設概況

\begin{tabular}{c|c|c|c}
\hline 項目 & $\begin{array}{c}\text { 野田線 } \\
\text { (上下線) }\end{array}$ & $\begin{array}{c}\text { 伊勢崎線 } \\
\text { (下り線) }\end{array}$ & $\begin{array}{c}\text { 伊勢崎線 } \\
\text { (上り線) }\end{array}$ \\
\hline 列車本数(本/日) & 204 & 318 & 302 \\
\hline ホ一ム数 & 1 & 1 & 1 \\
\hline 番 線 数 & 2 & 2 & 1 \\
\hline 改札口数 & \multicolumn{3}{|c}{} \\
\hline
\end{tabular}

表-2 通勤・通学時間帯の利用者数 $(7: 30 \sim 8: 29)$

\begin{tabular}{|c|c|c|c|c|}
\hline & 野田線 & $\begin{array}{c}\text { 伊勢崎線 } \\
\text { (下り) }\end{array}$ & $\begin{array}{c}\begin{array}{c}\text { 伊勢崎線 } \\
\text { (上り) }\end{array} \\
\end{array}$ & 降車客数 \\
\hline 野田線 & & 1,200 & 6,400 & 1,400 \\
\hline $\begin{array}{c}\text { 伊勢崎線 } \\
\text { (下り) }\end{array}$ & 3,000 & & - & 1,800 \\
\hline $\begin{array}{c}\text { 伊勢崎線 } \\
\text { (上り) }\end{array}$ & 2,800 & - & & 1,000 \\
\hline 初乗り客数 & 1,100 & 500 & 5,400 & \\
\hline
\end{tabular}

\section{4. 歩行者挙動データの取得}

本研究では, ビデオ映像（動画）を0.5秒毎のビデオ 画像 (静止画) として分割し, それらの画像より歩行者 の軌跡デー夕の取得を行なう. 1台のカメラから得られ る映像を用い, 図ー4〜図ー7に軌跡デー夕を取得する 一連の流㧈を示す。

また，図一8は，2 台のカメラから取得している2人 の歩行者の軌跡図である. 2 台のカメラから個別に取得 された同一地点の座標値は, カメラの設置方向やアフィ ン変換時の䛊差を含んでいるため, 図ー9に示すように 

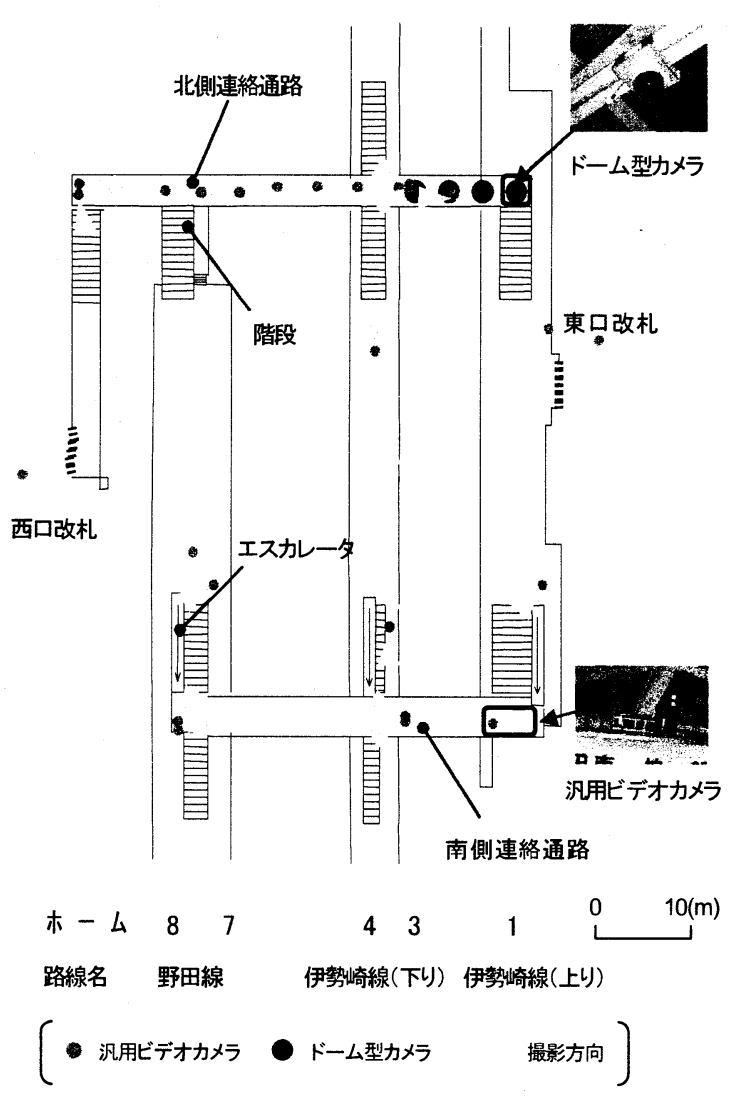

図－3 駅構造とビデオカメラの設置箇所

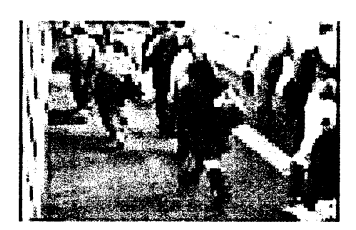

図ー4 頭部へのマーギグ

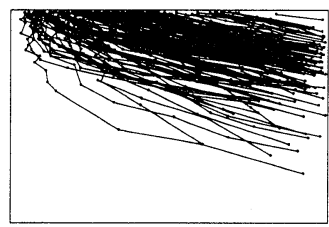

図一6ビデオ画像座標

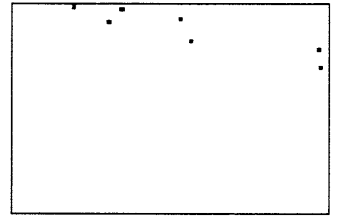

図ー5 マーギグ箇所の抽出

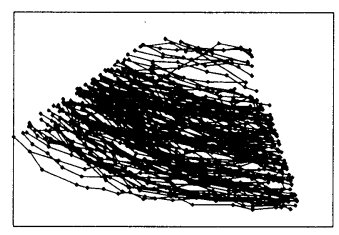

図-7 測地座標への変換
両者の座標系を移動, 回転する必要がある. さらに図 -10 に示すように, 2 台のカメラにより座標值を取得 している領域では, 両座標值の中点を採用することで, 連続した軌跡図を作成することは可能である. しかしな がら, このような複数のカメラから得られる移動軌跡を 接合する標定作業については，人的な作業によるところ が多い，そのため，長区間にわたる移動軌跡を大量に取 得できるよう, 現在, 自動処理システムを開発中である.

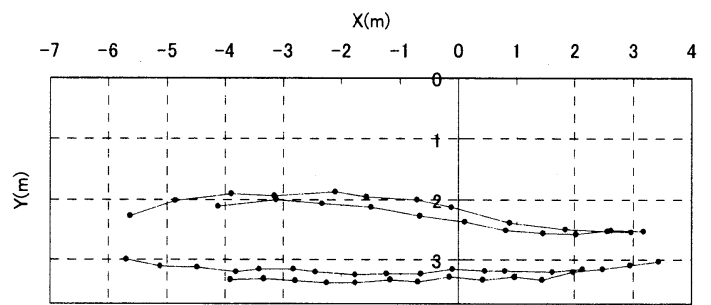

図ー8２台のカメラにより取得される軌跡図

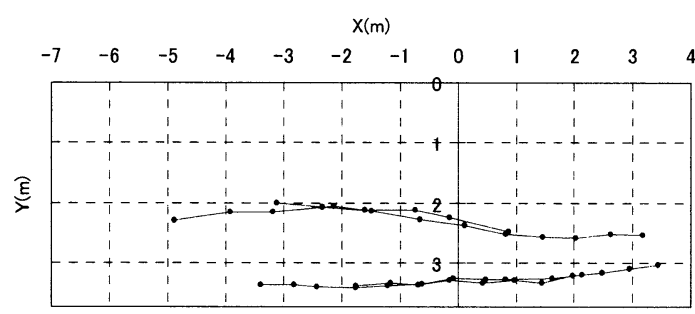

図一9 座標軸回転後の軌跡図

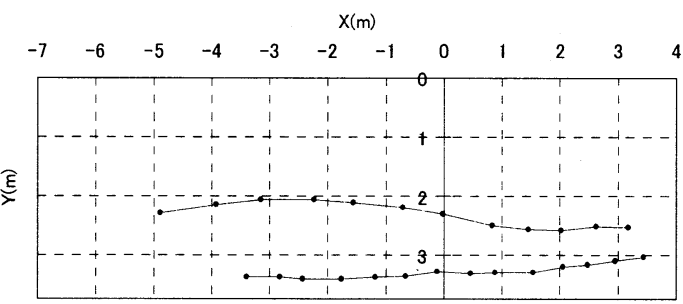

図-10 統合後の軌跡図

\section{5. 歩行者挙動特性分析}

ビデオ映像の観測および4次元パスデータより, 春 日部駅構内における歩行者挙動特性について整理する. なお, 本分析では, 混雑時の通路区間における歩行者 挙動に着目することから, 混雑現象が多く観測される 北側連絡通路の西口階段と野田線ホーム連絡階段間の 平日7時台のビデオ映像を使用する．また，この時間帯 においては，立ち止まり，逆戻り，回遊等の特殊な歩 行者挙動は観測されていない.

\section{（1）歩行者流の特性}

図ー11より, 歩行者が少ない閑散時には各自が比 較的自由に歩行しているが，歩行者が多くなるにつれ て左側を通行するようになる傾向がある，さらに， 混雑時の軌跡を示した図ー12より，歩行者の多い流 れの方が広く歩行スペースを占有していることが見 て取れる.

\section{(2) 歩行速度}

4次元パスデータより, 各歩行者の歩行速度を算出 
することが可能である．対象エリアにおけるデー夕 より平均歩行速度を算出し, 図一13に示す．なお, サンプル数は 313 人, 平均歩行速度は $2.00 \mathrm{~m} / \mathrm{s}$ ，標 準偏差は $0.55 \mathrm{~m} / \mathrm{s}$ である.これらより, 通勤・通学 時には，かけ足程度の速い速度で歩行しており，そ の分布は正規分布のようになっていることが確認で きる. なお，ここで得られる平均歩行速度分布を後 述する歩行者シミュレーションモデルにおいて各歩 行者に設定する初期值として利用する.

\section{(3) 交錯現象}

先述のように, 連絡通路において混雑時には歩行 者流が，二方向の対向流となる. そのため, 西口改札 から入場し, 野田線のホームに行く場合等において は，図ー14に示すような交錯が発生する．ビデオ映 像による観測では，対向流を横断する歩行者は，対 向者との距離等から横断する夕イミングを判断して いると考えられ，歩行者同士の接触や対向者の停止 等は見られない．図一14における横断者と対向者の 相対距離と速度の関係の一例を図一15に示す，両者 とも歩行速度が平均歩行速度の半分程度になってい ることが見て取れる．また，この例においては，対 向流を横断する歩行者は，対向者との距離が短くな るにつれ速度を上げ，逆に対向者は速度を下げてい るという関係が見て取れる. 横断者と対向者との関 係はその時々の状況によって異なるが，交錯時には 各歩行者が共に速度調節を行ない, 接触を避けてい ることが読み取れる。
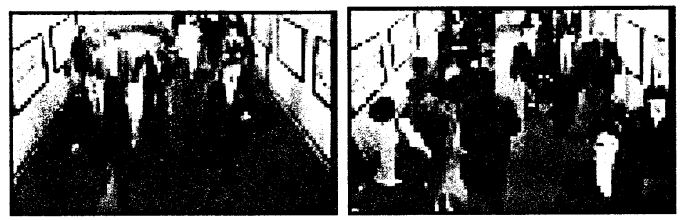

図-11 歩行者流の特性(左:閑散時 右:混集時)

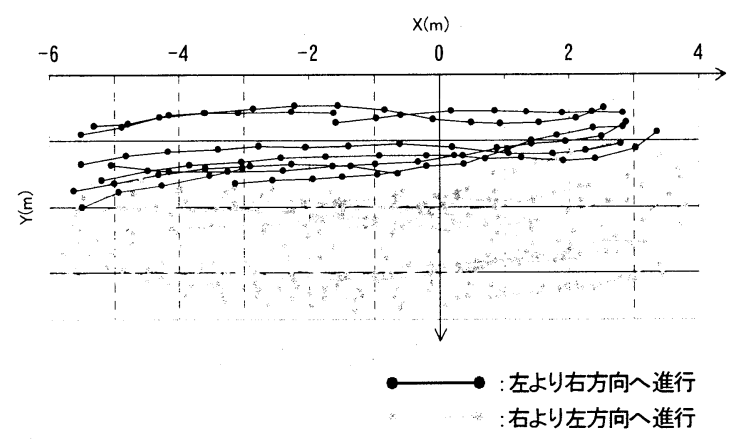

図ー12 混雑時における軌跡図の一部
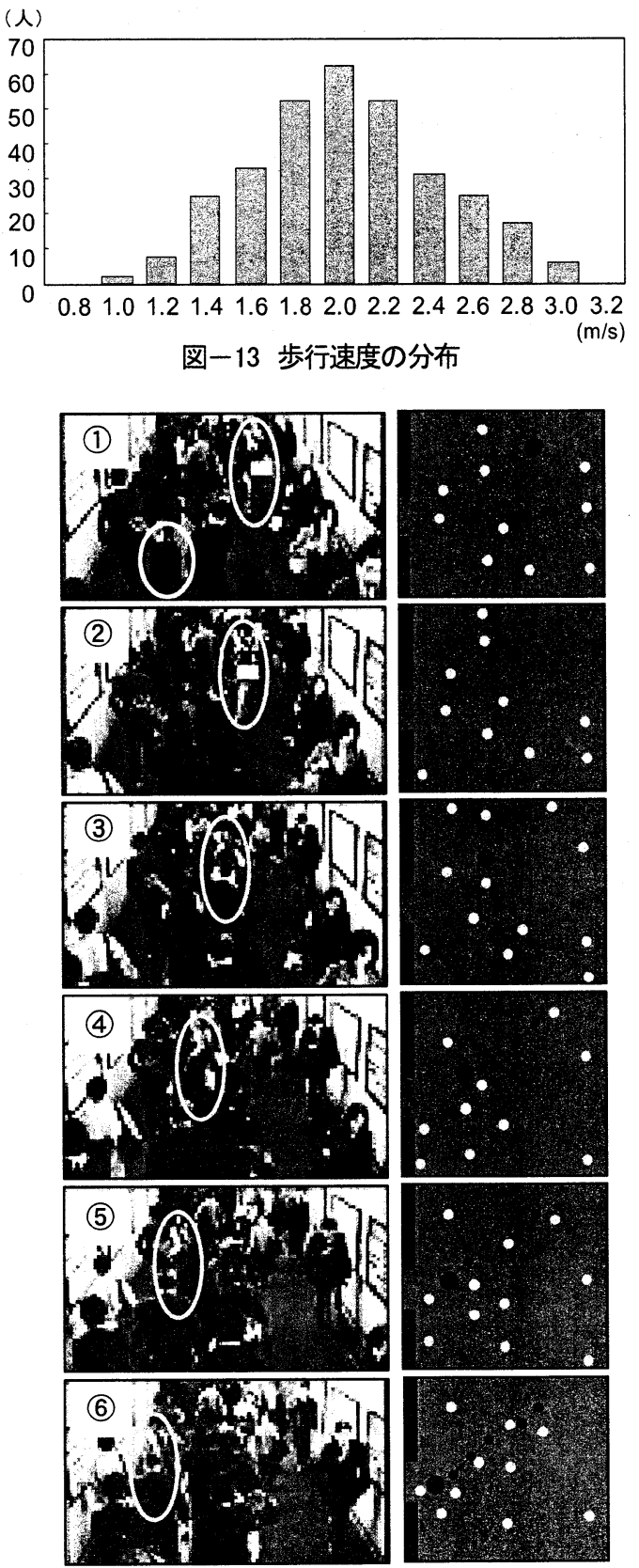

図-14 交錯時の軌跡図

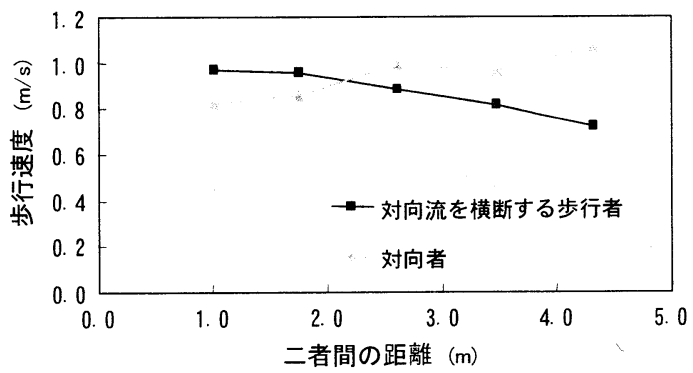

図一15 交錯時における二者間の距離と速度の関係 


\section{6. 鉄道駅構内歩行者シミュレーションモデルの構築}

歩行者挙動特性は, 磁気モデル $\left.{ }^{11)} \sim 15\right)$ とセルオート マトン法(1) 18) の長所を組合せることにより表現する. 各歩行者の設定および歩行者挙動のアルゴリズムを 以下に示す. また図ー16にシミュレーション実行画 面を示す。

\section{(1) 各歩行者の設定}

(1) 図一13に示す午前7時台の歩行速度分布に基づ き，各歩行者に初期速度を設定する.

(2) ビデオ映像より各階段からの流入・流出歩行 者数を観測し, 流入歩行者数を階段別流出率で 按分することにより OD表を作成する（流入出 口である階段が5箇所あるため，ODパターンは 20パターン）。OD表に基づき各歩行者に出発 地, 目的地を設定する. なお, 本シミュレーシ ヨンでは, $7: 30 〜 7: 40$ に北側連絡通路を通 行する 1,513 人を対象とする.

(2)歩行者挙動のアルゴリズム

(1) 歩行空間を $20 \mathrm{~cm} \times 20 \mathrm{~cm}$ のセルに分割し, 歩 行者の人体は $60 \mathrm{~cm} \times 60 \mathrm{~cm}$ （セル9個分）で表 現する. これは, Fruin ${ }^{21)}$ による人体棈円を参

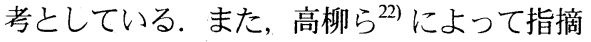
されているように, 歩行者には, 障害物や他の 歩行者によって干渉されるとストレスを感じる 干渉領域があると考えられる. 本研究において もこの干渉領域を考え, 歩行者の周りに設定す る. 領域の設定を図一17に示す。

(2) 歩行者の中心が1ステップ (0.5秒) で移動可能 な領域を歩行領域として設定する. $(\mathrm{n}+1)$ ス テップ目の歩行領域は, $\mathrm{n}$ ステップ目の歩行速 度で決定される. 例えば, $\mathrm{n}$ ステップ目の歩行 速度が $2.00 \mathrm{~m} / \mathrm{s}$ のとき, $(\mathrm{n}+1)$ ステップ目の歩行 領域は, 図一17のようになる。

（3）各セルに初期值として一定の磁荷を設定する. 歩行者流の特性より, 左側通行になる傾向が確 認されているため, 進行方向に対して通路左側 の磁荷を右側よりも相対的に小さく設定してい る. また, セルが壁や柱等の障害物や他の歩行 者の場合は, 相対的に磁荷が大きくなるよう計 算される. 歩行者は，歩行領域内のセルを中心 とする9つのセルにおける磁荷の合計が最も小 さいセルに進むよう近傍則を設定している. 歩 行領域，干渉領域の混雑状況により各セルの磁 荷は変化する.
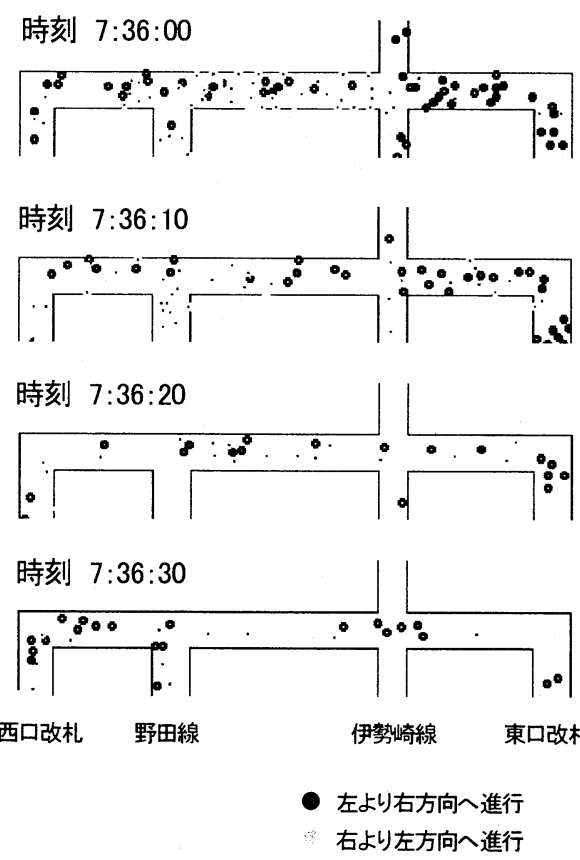

図ー16 シミュレーション実行画面

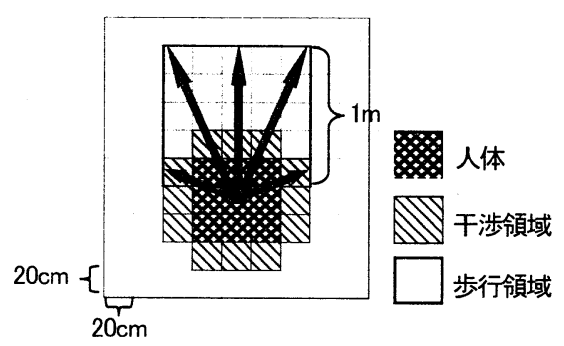

（步行領域は，歩行速度が $2.00 \mathrm{~m} / \mathrm{s}$ の場合）

図-17 歩行者の設定

\section{7. モデルの検証}

本研究では, 10回のシミュレーションを実行してい る. モデルの検証に際しては, 10回のシミュレーショ ン結果の平均值と実測値を比較する.

\section{（1）位置座標による再現性の検証}

西口階段と野田線ホーム連絡階段間の通路を

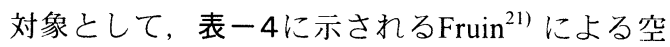
間モデュールが「D」となる状況下での各歩行 者の1ステップ毎の位置座標を確認する. シミュ レーション実行時間7 : 30〜 7 : 40のうち, 複数 の列車の発着が集中する7 : 35〜 7 : 38に着目す ると空間モデュールが「D」となる時間が31秒 間発生している。この対象区間を通行している 歩行者数は103名である. 対象区間においてこれ 
表ー3 移動パスによる再現性の検証

\begin{tabular}{c|c}
\hline 許容誤差 & 再現性 \\
\hline 0 セル & $2.1 \%$ \\
\hline \pm 1 セル $( \pm 20 \mathrm{~cm})$ & $14.1 \%$ \\
\hline \pm 2 セル $( \pm 40 \mathrm{~cm})$ & $41.4 \%$ \\
\hline \pm 3 セル $( \pm 60 \mathrm{~cm})$ & $67.5 \%$ \\
\hline
\end{tabular}

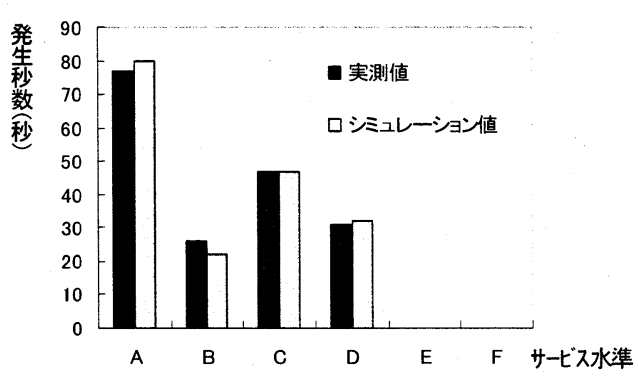

図一18 集計量による再現性の検証

らの歩行者を0.5秒単位で追跡すると, 延べ 916 サンプル（位置座標）が取得される。このサン プルをもとに, $\mathrm{n}$ ステップ目の位置座標の実測值 をモデルに入力し, 計算される $(\mathrm{n}+1)$ ステップ目 の位置座標と実測値を比較した結果が表一ろで ある．完全に再現するまでには至っていないも のの, 前後左右 \pm 3 セル $(60 \mathrm{~cm}: 1$ 人の歩行者の 大きさに相当）までを許容誤差とすると $67.5 \%$ の再現性が得られている.

\section{（2）集計量による再現性の検証}

7 : 35〜 7 : 38における空間モデュールのサー ビス水準別発生秒数を示したものが図ー18であ る. 先述のように区間内における歩行者挙動に は誤差が残るものの，一定の時間内における空 間モデュールはほぼ再現できていると考えられ る。また，これまで筆者らがセルオートマトン 法のみで構築したシミュレーションモデル ${ }^{18)}$ りも高い再現性が得られている.

\section{(3)タイムオキュパンシー}

シミュレーション結果による10分間の各セル におけるタイムオキュパンシーを図ー19に示す。 ビデオ映像の観測で交錯現象が多く見られた野 田線ホームへの階段付近のタイムオキュパンシ 一が高いことが見て取れる. また，西口および 東口改札への階段付近には, あまり利用されて いないスペースがあることが確認できる．この ように, 有効に活用されていないスペースや滞 留が発生しやすいエリアを視覚的に確認するこ とで有効な空間利用の検討が可能になる.
表ー4 空間モデュールによるサービス水準

\begin{tabular}{|c|c|c|}
\hline $\begin{array}{l}\text { サービス } \\
\text { 水準 }\end{array}$ & $\begin{array}{c}\text { 空間モデュール } \\
\left(\mathrm{m}^{2} / \text { 人) }\right.\end{array}$ & 説 明 \\
\hline A & $3.5 \sim$ & $\begin{array}{l}\text { 颫い人を追い抜いたり，好きな歩行速度を自由に } \\
\text { 選択でるる. }\end{array}$ \\
\hline B & $2.5 \sim 3.5$ & $\begin{array}{l}\text { 大部分が同じ方向に歩いている流動ならば他人 } \\
\text { を追い抜くことが可能 対向流や交差流のあると } \\
\text { ころでは, 衝突の可能性かわずかにある. } \\
\end{array}$ \\
\hline C & $1.5 \sim 2.5$ & $\begin{array}{l}\text { 各自が步行速度を選択したり，追い拔いたりする } \\
\text { 自由度は制限される. 対向流や交差流の存在す } \\
\text { る所では衝突の生じる確率が高い. }\end{array}$ \\
\hline D & $1.0 \sim 1.5$ & 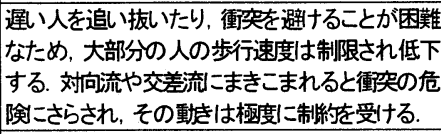 \\
\hline$E$ & $0.5 \sim 1.0$ & 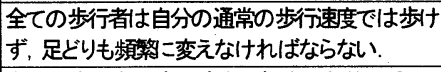 \\
\hline$F$ & $\sim 0.5$ & $\begin{array}{l}\text { 全ての歩行者の歩行速度は極度に制約を受け, } \\
\text { 前進はずり足でしかできななる. }\end{array}$ \\
\hline
\end{tabular}

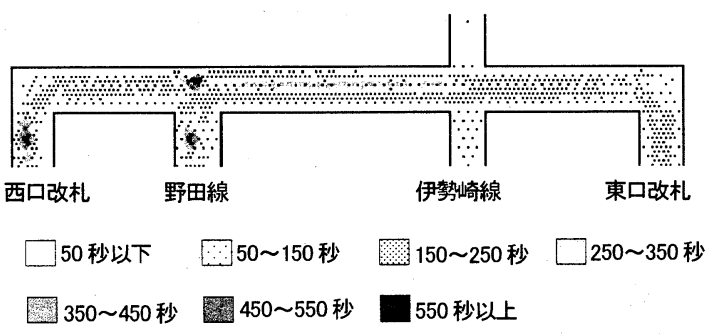

図ー19 タイムオキュパンシー(7:30 7:40)

\section{8. おわりに}

本研究では, 歩行者挙動を考慮した鉄道駅整備を目 標とし, そのための分析として, 監視カメラを模した ビデオカメラにより得られる映像からの歩行者挙動デ 一夕の取得, そのデータを基にした歩行者挙動特性分 析および歩行者挙動のモデル化を試みている.

歩行者挙動特性分析では, 現状の春日部駅で見られ る基本的な歩行者挙動として, 歩行者流の特性, 歩行 速度, 交錯現象における相対距離と歩行速度の関係を ビデオ画像や 4 次元パスデー夕より分析し, 歩行者挙 動の傾向を捉えている. しかしながら，毎時，毎時の 歩行者挙動とその時の周辺状況との関係について知見 を得るには至っておらず, さらに詳細な分析を行なう 必要がある. 歩行者挙動のモデル化に関しては, 混雑 時における歩行者の 1 ステップ毎の位置座標を確認し, 歩行者 1 人分の大きさを許容誤差とすれば, 7 割程度 の再現性が確保できることを示している. また，一定 の時間内における空間モデュールの発生秒数はほぼ再 現できていることを示している. 先述のとおり, 個々 の歩行者挙動を十分に反映しきれていないため, 個々 の歩行者の移動軌跡に関しては誤差が残るものの, 空 間モデュールのような集計量で表現するものに関して 
は一定の成果を得ている. また, シミュレーション結 果から空間の利用状況を把握することが可能であるた め, 整備案による空間利用状況の変化を視覚的に捉え, 滞留が生じる可能性がある箇所やデッドスペースの存 在を計画段階で確認することが可能である．これらの 結果をフィードバックすることにより, 効果的な整備 案の検討が可能になるものと考える. なお，本研究で は通勤・通学時間帯のある限定的な区間において見ら れる歩行者挙動の一端をシミュレーションモデルへ反 映したに過ぎず，高齢者，身障者，幼坚等の挙動特性 や立ち止まり, 逆戻り, 回遊といつた特殊な歩行者挙 動, 時間帯, 曜日等による歩行者流の変動等を反映す るまでには至っていない. 今後, 他のカメラや時間帯 で得られたビデオ映像を基にこれらについても検討し ていくことが必要である. また, より効率的に 4 次元 パスを取得できるよう画像処理システムの改良を進め ること, 長区間にわたる歩行者の移動軌跡を自動処理 するシステムの開発を進めること, 得られる長区間の 移動軌跡によりモデルの検証を行なうことも課題とし て挙げられる.

駅構造, 利用客数, 混雑する時間帯, 利用客の属性 等は，駅により様々である. これまでのような画一的 な整備ではなく, 各駅の特性を考慮した整備を行なう ことが求められている. そのため, 各駅における歩行 者の動きをより正確に観測し，そこから得られる知見 を整備に活かしていくことは必要である. その際，既 存ストックを有効に活用することが望ましい，本研究 で提案するアプローチを積極的に取り入れ，真の快適 空間実現のための検討を続けていくべきである. 最後 に, 本研究における一連の手法は，このことを達成する 大きな一歩を示したと結論づける.

謝辞 : 本研究を遂行するにあたり, 当時東京理科大学の大学院 生であり, 現東日本旅客鉄道株式会社の中山泰成氏, 現東京理 科大学大学院の関口岳史氏の寝食を忘れた努力があった. また, 春日部駅における調査では, 東武鉄道株式会社のご協力をいた だいた. 撮影に際しては, 株式会社道路計画, 株式会社NTTデ 一タよりビデオカメラ等の機材を提供していただいた. ここに 記して深謝の意を表する. なお, 本研究は, 文部科学省科学研 究費（若手研究（B）15760401）の研究助成を受けて実施され たものである.

\section{参考文献}

1) 森地: 東京圈の鉄道のあゆみと未来, (財)運輸政策吥究機構, 2000.

2) 東口本旅客鉄道株式会社:ニューフロンティア 2008 - 新た な創造と発展, JR東口本グループ巾期経営構想 2005-2008, 2005. (http://www.jreast.co.jp/investor/nf2008/pdf/01.pdf)
3) 家田: 「駅の目的地化」をす寸めよう, 連輸と経済, 第64巻 第10号, pp.13-16, 2004.

4) 白井ら:複雑背景における人の追跡, 情報処理学会論文誌, Vol.43 No.SIG04 (CVIM4), pp.33-42, 2002.

5) 口比野ら:鉄道駅における歩行者データの取得および活用 方法に関寸る一考察, 土木計画学破究·論文集, Vol.21 No.3, pp.781-787, 2004.

6) 北澤ら:駅構内における移動者の空間行動計測と分析, 土木 計画学研究·講演集 No.27, 2003.

7）朝倉ら:PHSによる位置情報を用いた交通行動調查手法, 土 木学会論文集, No.653/IV-48, pp.95-104, 2000.

8) 加藤ら: 群集対向流動の解析, 口本建築学会論文報告集, 第 289号, pp.119-129, 1980.

9) 高柳ら:群集交差流動における歩行領域確保に関寸る研究 一歩行領域モデルを用いた解析一, 口本建築学会計画系論 文集, Vol.549, pp.185-191, 2001.

10）金森:移動効用を考慮した駅構内における人間の歩行シミュ レーション, 巾央大学大学院理工学研究科情報工学専攻修士 論文, 2004.

11) 岡崎:建築空間における歩行のためのシミュレーションモデ ルの研究 その1 磁気モデルの応用による歩行モデル, 口本 建築学会論文報告集, 第283号, pp.111-117, 1979.

12) 岡崎: 建築空間における歩行のためのシミュレーションモデ ルの吥究 その2 混雑した場所での歩行, 口本建築学会論文 報告集, 第284号, pp.101-108, 1979.

13) 岡崎: 建築空間における歩行のためのシミュレーションモデ ルの研究その3 停滞や火災を考慮して最短径路を選ぶ歩行, 口本建築学会論文報告集, 第285号, pp.137-144, 1979.

14) 岡崎ら:建築空間における歩行のためのシミュレーションモデ ルの吥究その4 群集歩行の透視図による表現，口本建築学 会論文報告集, 第299号, pp.105-113, 1981.

15）岡崎ら:建築空間における歩行のためのシミュレーションモデ ルの䂧究その5 探菜歩行及び誘導標による歩行, 口本建築 学会論文報告集, 第302号, pp.87-93, 1981.

16) 森下ら:セルラオートマトン法による鉄道における人の流れ， 口本機械学会第6回交通·物流部門大会講演論文集 (鉄道シ ンポジウム編), pp.539-542, 1997.

17) 近田ら:CAを用いた歩行シミュレーションモデルの構築, 土 木情報システム論文集, Vol.9, pp.19-pp.30, 2000.

18）関口ら:乗換え歩行者行動に着目したシミュレーションモデル の構築, 鉄道技術連合シンポジウム, pp.265-268, 2004.

19) Hibino et al :A Study on Passengers' Flow at Railway Station Based on Individual Transfer Behavior, Proceedings of the $10^{\text {th }}$ World Conference on Transport Research, 13 pages, 2004.

20）内閣府 国民生活局:個人情報の保護に関する法律, 2005 .

21) Fruin著, 長島訳:歩行者の空間一理論とデザインー, 鹿島出 版会, 1974.

22）高柳ら: 時系列領域干渉負荷モデルを用いた歩行者空間の 混雑評価に関寸る研究, 第23回情報システム利用技術シン ボジウム論文集, pp.163-168, 2000. 


\section{鉄道駅におけるモニターカメラから得られる歩行者挙動データの活用に関する研究 *}

日比野 直彦 $* *$, 山下 良久 $* * *$, 内山久雄

高齢化社会等の社会的背景により, 鉄道サービスの改善が強く求められている. 空間的, 予算的制約がある中で, これまで のような大規模整備を行なうことは困難であることから, 近年, 鉄道事業者は, 鉄道駅に重点をおいた施策を展開している. しかしながら, 駅構内における混杂等, 未だ改善されない問題は多く早急な対応が求められている.このような問題に対し, これまで筆者らは, 駅構内の歩行者挙動を考慮した駅整備の必要性を指摘し,ビデオ映像から自動的に歩行者の4次元パ スデータを取得するシステムを開発している. 本研究では, 歩行者の4次元パスデータより歩行者挙動の特性を把握し, 歩 行者シミュレーションモデルの開発を試みる.

\section{A Study on Usage of Pedestrian Behavioral Data from Video Camera in Railway Stations *}

\section{By Naohiko HIBINO**, Yoshihisa YAMASHITA*** and Hisao UCHIYAMA****}

The level of service in a station is influenced by not only station facilities but also congestion etc. Therefore, railway station improvements in consideration of passengers' behavior are very important. It is, however, difficult to effectively acquire the pedestrian transferring data. On the other hand, the system for automatically obtaining pedestrian 4dimensionality path data from the video images has been proposed by the authors. This study uses the system in order to obtain the data and tries to model the pedestrians' behavior in the station. The study discusses some of usages of pedestrian behavioral data for better improvement of stations. 